\title{
EVALUATION OF TOTAL PHENOLIC, FLAVONOID CONTENT, AND DPPH FREE RADICAL SCAVENGING ACTIVITY OF METHANOLIC EXTRACT OF AILANTHUS EXCELSA ROXB
}

\author{
ARUNA KUMARI*, SHARMA RA \\ Department of Botany, Plant Physiology and Biochemistry Laboratory, University of Rajasthan, Jaipur, Rajasthan, India. \\ Email: apayal88@gmail.com
}

Received: 07 December 2016, Revised and Accepted: 29 December 2016

\section{ABSTRACT}

Objective: Estimation of total phenol, flavonoid, and antioxidant activity of various plant parts (leaves, stem, root, flower, and fruit) of Ailanthus excelsa Roxb. methanolic extracts.

Methods: Different plant parts were extracted with methanol, then the total phenol content was calculated using Folin-Ciocalteu reagent, total flavonoid content was estimated using aluminum chloride colorimetric method and the antioxidant activity was measured by 1,1-diphenyl-2picrylhydrazyl radical assay.

Results: The highest total phenolic content $48.38 \mathrm{mg}$ gallic acid equivalent [GAE]/gdw was observed in flower and lowest phenolic content in root (28.56 mg GAE/gdw). The highest total flavonoid content (21.5 mg quercetin equivalent [QE]/gdw) was found in leaf and lowest in root (1.11 mg $\mathrm{QE} / \mathrm{gdw}$ ). The highest radical scavenging activity was found in flower extracts with the inhibitory concentration value of $36.85 \mu \mathrm{g} / \mathrm{ml}$ and the lowest scavenging activity was observed in root extract that was found to be $1493.46 \mu \mathrm{g} / \mathrm{ml}$.

Conclusion: According to the results of present investigation the plant showed significant antioxidant activity that can be used for medical purpose for the treatment of various diseases.

Keywords: Antioxidant activity, Ailanthus excelsa Roxb., Total phenolic content, Total flavonoid content, 2,2-diphenyl-1-picrylhydrazyl, Scavenging activity.

(C) 2017 The Authors. Published by Innovare Academic Sciences Pvt Ltd. This is an open access article under the CC BY license (http://creativecommons. org/licenses/by/4. 0/) DOI: http://dx.doi.org/10.22159/ajpcr.2017.v10i4.16507

\section{INTRODUCTION}

An oxidative stress is the result of free radicals, which form stable electron pairing with biological macromolecules such as proteins, lipids and DNA in healthy human cells and cause protein and DNA damage along with lipid peroxidation. It is answerable for many of today's diseases that results from an imbalance between formation and neutralization of pro-oxidants [1].

In defense against this oxidative stress, body have their own system including various enzymes, proteins, and vitamins, which are known as antioxidants. The level of antioxidants declines in body with the increasing age which requires external source of antioxidants to defend [2]. Currently, there has been an increased interest globally to identify antioxidant components that are pharmacologically effective and have low or no side effects for use in preventive medicine and food industry [3]. Plants are good sources of natural antioxidants such as vitamins, polyphenolic compounds and other secondary metabolites for the human diet, containing several different antioxidant compounds which provide defense against detrimental free radicals and have been sturdily associated with reduced risk of chronic diseases, in addition to other health benefits [4]. These natural phytoproducts show the antioxidant activity due to their redox properties, which allow them to act as reducing agents, hydrogen donators, singlet oxygen quenchers, and metal chelators $[5,6]$

According to the research studies, the antioxidant activity of plants might be due to their phenolic compounds [7]. Similarly, various flavonoids isolated from medicinal plants have been reported with antioxidative, anti-inflammatory, estrogenic, antimicrobial, antiallergic, cardiovascular, and cytotoxic antitumor activities [8]
Ailanthus excelsa Roxb (family: Simaroubaceae) is a tree of rapid growth and is called tree of heaven, leaves appear in March-April, $30-90 \mathrm{~cm}$ long, pinnate, the flowers, small in size, yellow in color and arranged in panicles and the fruits are formed soon after flowering. The fruits ripen in May-June, just before the onset of monsoon. A. excelsa was investigated previously to prove antibacterial [9], antifungal [10], antifertility [11], and anticancer [12]. A. excelsa is used in treatment of skin eruption and for the cure of wounds, the bark is bitter, astringent, anthelmintic, febrifuge, appetizer, bitter tonic, taste bud stimulant, it is useful in diarrhea, amebic dysentery, chronic giardiasis, dyspepsia, abdominal spasm anorectal disease, hemorrhoids, fistula, fissures, ulcerative colitis as mentioned in traditional medicine [13]. From chemical point of view, the plant is a rich source of alkaloids $[14,15]$, proteins [16], quassinoids $[17,18]$, and flavonoids were isolated from leaves [19]. Therefore, this study was carried out to investigate the comparison of antioxidant activity of different plant part of A. excelsa Roxb. There are no data previously about the comparison of various plant parts of the plant. Therefore, the plant is quite medicinal having potent antioxidant activity and can be used in pharmaceutical industry for the preparation of new drugs.

\section{METHODS}

\section{Collection of plant material}

Plant parts (leaves, stem, root flower, and fruit) of A. excelsa Roxb. were collected from the University of Rajasthan campus, Jaipur. The material was brought to the laboratory, washed with tap water and air dried at room temperature. After drying, the samples were powdered using grinder milland stored in desiccators. Herbarium samples were deposited and verified in the Department of Botany, University of Rajasthan, Jaipur, Rajasthan, India, and got the voucher specimen no. 211591. 
Preparation of plant extracts

About $10 \mathrm{~g}$ powder of different plant parts of $A$. excelsa Roxb. was placed in Soxhlet extractor separately. It was extracted with methanol for approximately $48 \mathrm{hrs}$ and filtered through Whatman paper no 1 filter paper. After filtration, the solvent collected from the extractor was evaporated. The concentrated residue obtained which contains the plant extract and stored for further use.

\section{Determination of total phenolic content}

The content of total phenol in methanolic extracts of A. excelsa Roxb. plant parts (leaves, stem, root flower, and fruit) was determined spectrophotometrically using Folin-Ciocalteu reagent [20] with modifications. Calibration curve was prepared by mixing methanolic solution of gallic acid ( $1 \mathrm{ml} ; 50,100,150,200,250 \mu \mathrm{g} / \mathrm{ml}$ ) with $5 \mathrm{ml}$ Folin-Ciocalteu reagent (diluted tenfold) and sodium carbonate solution in distilled water $(4 \mathrm{ml}, 0.7 \mathrm{M})$. The absorption was measured at $765 \mathrm{~nm}$ using a ultraviolet-visible (UV-VIS) spectrophotometer. $1 \mathrm{ml}$ of plant extracts was mixed instead of 1 ml gallic acid with the same reagents as described above in three different test tubes and after $1 \mathrm{hr}$ the absorption was measured to determination of the total phenolic contents. The absorbance was measured against a reagent blank, which was composed of the same reagents except test extract. Total content of phenolic in the plant extracts was expressed as gallic acid equivalents (mg of GAE/g sample) and were calculated for each sample.

\section{Determination of total flavonoids content}

The total flavonoid in the crude extracts was evaluated using the aluminum chloride colorimetric method [21]. To $1 \mathrm{ml}$ of plant extract or standard of different concentrations $3 \mathrm{ml}$ methanol, $0.2 \mathrm{ml}$ of $10 \%$ aluminum chloride, $0.2 \mathrm{ml}$ potassium acetate $(1 \mathrm{M})$, and $5.6 \mathrm{ml}$ of distilled water were added. Then the solution was incubated for 30 minutes at room temperature. The absorbance was measured at $415 \mathrm{~nm}$ using UV spectrophotometer against a blank. Standard curve was prepared using quercetin by dissolving it in methanol followed by serial dilution to $25,50,100,200 \mu \mathrm{g} / \mathrm{ml}$. Total content of flavonoid in the plant extracts was expressed as quercetin equivalents ( $\mathrm{mg}$ of QE/g sample) and were calculated for each sample.

Determination of 2,2-diphenyl-1-picrylhydrazyl (DPPH) free radical scavenging activity

The free radical scavenging activities of the plant extracts were measured using the modified method of Blois [22]. $1 \mathrm{ml}$ each of the different concentrations of extracts or standard (vitamin C) in a test tube was added $1 \mathrm{ml}$ of $0.3 \mathrm{mM}$ DPPH in methanol. The mixture was vortexed and then incubated in a dark chamber for 30 minutes after which the absorbance was measured at $517 \mathrm{nM}$ against a DPPH control containing only $1 \mathrm{ml}$ of methanol in place of the extract. Percentage scavenging activity was calculated using the expression [23].

$$
\% \text { scavenging activity }=\frac{\begin{array}{l}
\text { Absorbance of control } \\
\text { Absorbance of sample }
\end{array}}{\text { Absonce of control }} \times 100
$$

\section{Statistical analysis}

All parameters such as antioxidant activity, total phenolic content, and flavonoid content were performed in triplicate for each independent sample to be analyzed. All data were expressed as mean \pm standard deviation. Linear regression analysis was applied to calculate inhibitory concentration $\left(\mathrm{IC}_{50}\right)$ value.

\section{RESULTS AND DISCUSSION}

\section{Total phenolic and flavonoid content}

The antioxidant activity of phenolics is mainly due to their redox properties, which allow them to act as reducing agents, hydrogen donors and singlet oxygen quenchers [24]. Phenolic compounds from plants belong to a class of bioactive compounds that have received much attention during recent years, mainly owing to their positive effects on diet-health interaction in human nutrition [25] and antioxidants have capacity to mobilize protective effects against oxidative stress due to their high antioxidant activity [26].

Table 1 shows the contents of total phenolics and flavonoids. Total phenolic contents were measured by Folin-Ciocalteu reagent in terms of GAE. The results revealed that total phenolic contents vary among different plant parts. The flower methanolic extracts showed highest phenolic content (48.38 mg GAE/gdw) and decreases in the order fruit (36.12 mg GAE/gdw), leaves (36.04 mg GAE/gdw), stem (32.28 mg GAE/gdw), and root (28.56 mg GAE/gdw).

Total flavonoid contents were measured by aluminum chloride method in terms of QE. Maximum flavonoid content was observed in leaves (21.5 mg QE/gdw) and decreases in the order stem (11.7 mg QE/gdw), flower (7.44 mg QE/gdw), fruit (5.24 mg QE/gdw), and root (1.11 mg QE/gdw).

\section{DPPH radical scavenging activity}

The DPPH scavenging assay is broadly used to assess the free radical scavenging of plant extracts due to its simple, rapid, sensitive, and reproducible procedure [27]

Table 2 shows the $\mathrm{IC}_{50}$ values of methanolic extracts of various samples of $A$. excelsa Roxb., that is, the measure of free radical scavenging activity by DPPH. From the results, it was observed that the flower extract exhibited the highest scavenging activity having lowest $\mathrm{IC}_{50}$ value that was found to be $36.85 \mu \mathrm{g} / \mathrm{ml}$ and lowest scavenging activity in the root extracts having highest $\mathrm{IC}_{50}$ value that was found to be $1493.46 \mu \mathrm{g} / \mathrm{ml}$. This activity might be due to the presence of phenolic compounds. The $\mathrm{IC}_{50}$ value of standard ascorbic acid was $17.30 \mu \mathrm{g} / \mathrm{ml}$.

The radical scavenging activity of the extract was observed from the decrease in absorbance of the DPPH with the extract with increase in concentration at $517 \mathrm{~nm}$. This revealed in the rapid discoloration of the purple DPPH to light yellow, suggesting that the radical scavenging activity of methanol extract of $A$. excelsa Roxb. was due to its proton donating ability. Linear regression curve between concentration and $\%$ inhibition of different plant parts were depicted in Figs. 1-5.

\section{CONCLUSION}

In conclusion, this study indicates that the extracts obtained from the various plant parts of $A$. excelsa Roxb. have significant free radical scavenging activity on stable DPPH and high reactive hydroxyl radical. The data depicts that the plant, A. excelsa Roxb. is a potential source of natural antioxidants.

Table 1: Total phenol and flavonoid content in A. excelsa Roxb.

\begin{tabular}{lll}
\hline $\begin{array}{l}\text { Plant } \\
\text { part }\end{array}$ & $\begin{array}{l}\text { Total phenolic content } \\
\text { (mg GAE/gdw) }\end{array}$ & $\begin{array}{l}\text { Total flavonoidal content } \\
\text { (mg QE/gdw) }\end{array}$ \\
\hline Leaves & $36.04 \pm 0.089$ & $21.5 \pm 0.037$ \\
Stem & $32.28 \pm 0.004$ & $11.7 \pm 0.013$ \\
Root & $28.56 \pm 0.006$ & $1.11 \pm 0.008$ \\
Flower & $48.38 \pm 0.016$ & $7.44 \pm 0.008$ \\
Fruit & $36.12 \pm 0.176$ & $5.24 \pm 0.025$ \\
\hline
\end{tabular}

A. excelsa: Ailanthus excelsa

Table 2: IC $_{50}$ values of different plant parts of $A$. excelsa Roxb

\begin{tabular}{ll}
\hline Plant part & IC $_{\mathbf{5 0}}$ values $(\boldsymbol{\mu g} / \mathbf{m l})$ \\
\hline Leaves & $466.28 \pm 16.33$ \\
Stem & $1313.92 \pm 14.22$ \\
Root & $1493.46 \pm 20.03$ \\
Flower & $36.85 \pm 4.23$ \\
Fruit & $221.83 \pm 17.87$ \\
\hline
\end{tabular}

A. excelsa: Ailanthus excelsa, $\mathrm{IC}_{50}$ : Inhibitory concentration 


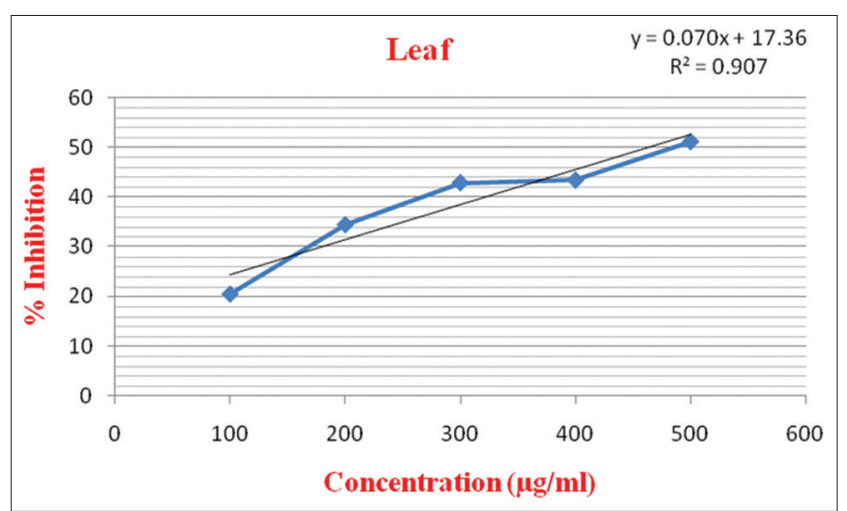

Fig. 1: 2,2-diphenyl-1-picrylhydrazyl radical scavenging activity of methanolic extract of Ailanthus excelsa leaf

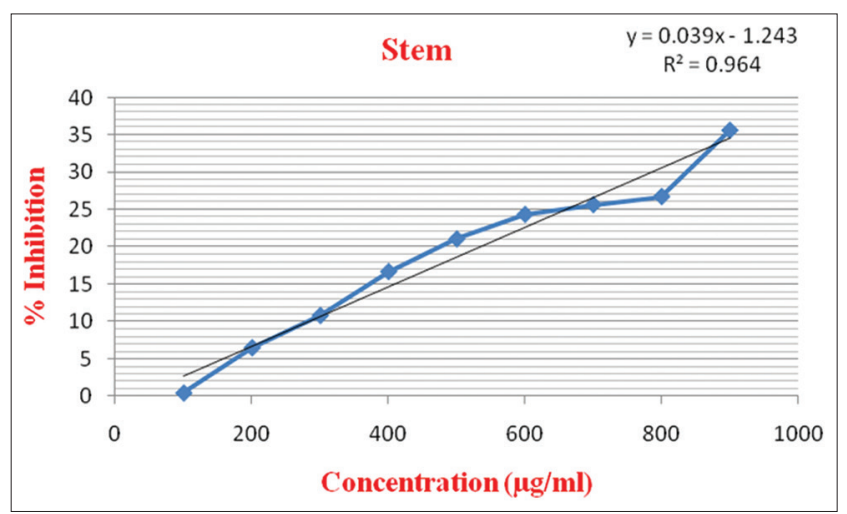

Fig. 2: 2,2-diphenyl-1-picrylhydrazyl radical scavenging activity of methanolic extract of Ailanthus excelsa stem

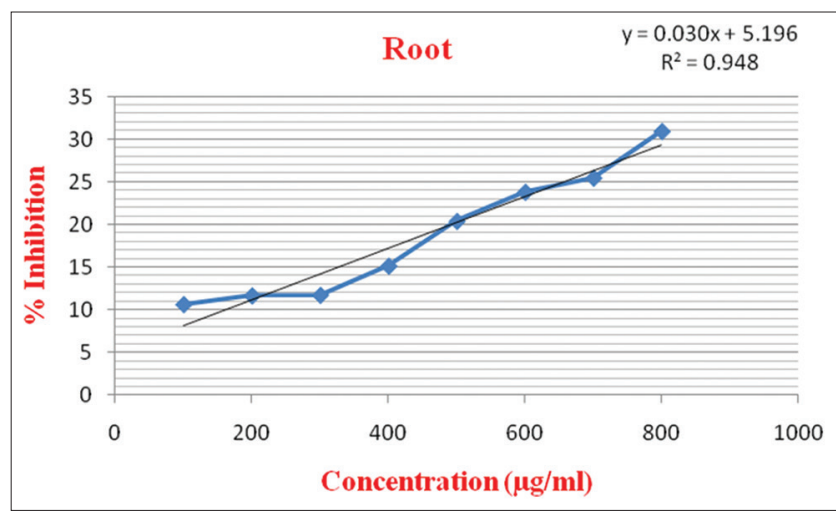

Fig. 3: 2,2-diphenyl-1-picrylhydrazyl radical scavenging activity of methanolic extract of Ailanthus excelsa root

In this study, antioxidant activity of methanolic extracts significantly differed among the various plant parts. Flower showed the highest antioxidant activity and root showed the lowest activity. The antioxidant activity of $A$. excelsa Roxb. as according to the previously proved research may be due to the presence of significant amount of phenolic compounds because phenolic compounds are the major contributors of antioxidant activity. As according to the previously proved research due to the presence of phenols and flavonoids and their correlation with total phenolic content and total flavonoid content, these studies suggest that phenols and flavonoids can be used to develop the novel phenolic synthetic antioxidants that can be applied to retard the effects of free radicals and oxidants [28-30]. Hence, further research is necessary to conduct on identification of bioactive compounds which are responsible for the antioxidant activity and can be applied for medical purpose in therapeutics.

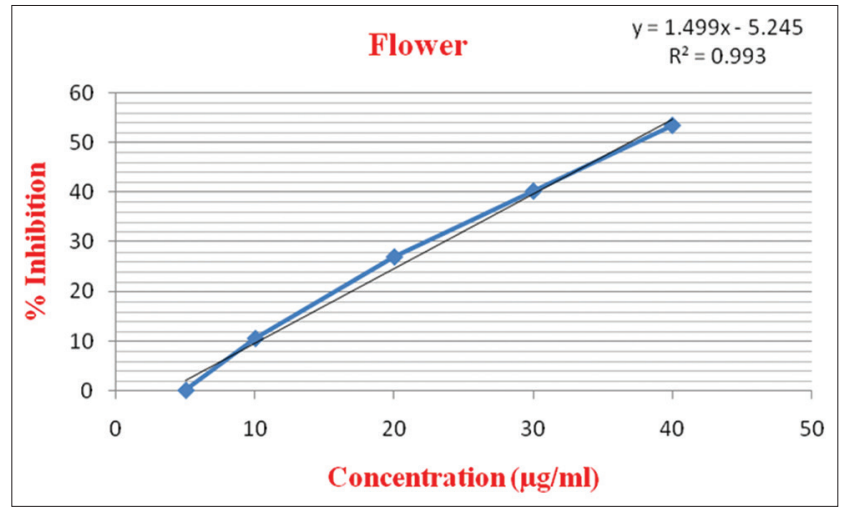

Fig. 4: 2,2-diphenyl-1-picrylhydrazyl radical scavenging activity of methanolic extract of Ailanthus excelsa flower

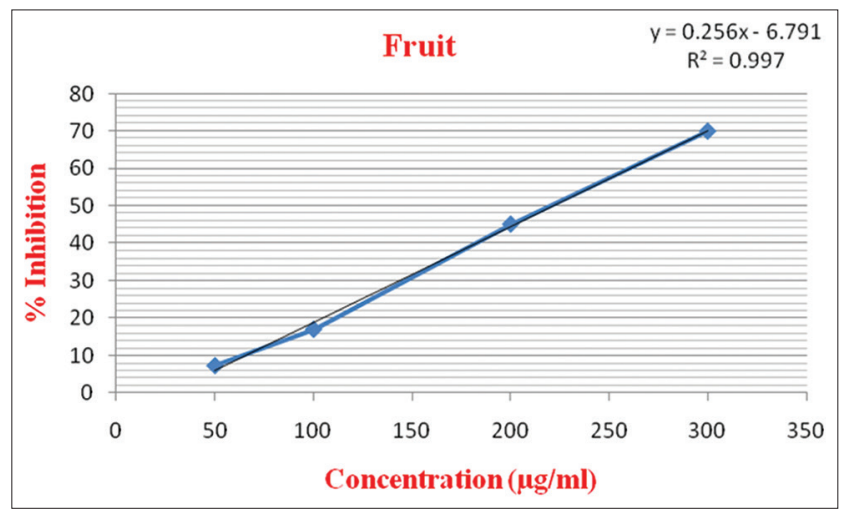

Fig. 5: 2,2-diphenyl-1-picrylhydrazyl radical scavenging activity of methanolic extract of Ailanthus excelsa fruit

\section{ACKNOWLEDGMENTS}

Author, Aruna Kumari, is grateful to UGC (University Grants Commission), New Delhi for financial support to providing UGC - BSR fellowship.

\section{REFERENCES}

1. Rajan S, Mahalakshmi S, Deepa VM, Sathya K, Shajitha S, Thirunalasundari T. Antioxidant potentials of Punica granatum fruit rind extracts. Int J Pharm Pharm Sci 2011;3(3):82-8.

2. Vadalia DN, Pethe AM, Chakraborthy GS. Antioxidant activity of polyherbal formulation. J Pharm Res 2010;3(8):1756-8.

3. Singh R, Jain SC, Jain R. Antioxidant activity of some medicinally important arid zone plants. Asian J Exp Sci 2009;23(1):215-21.

4. Krishnaiah D, Sarbatly R, Bon A. Phytochemical antioxidants for health and medicine - A move towards nature. Biotechnol Mol Biol Rev 2007;1(4):97-104.

5. Morel I, Lescoat G, Cillard P, Cillard J. Role of flavonoids and iron chelation in antioxidant action. Methods Enzymol 1994;234:437-43.

6. Rice-Evans CA, Miller NJ, Paganga G. Antioxidant properties of phenolic compounds. Trends Plant Sci 1997;2(4):152-9.

7. Cook NC, Samman S. Flavonoids-chemistry, metabolism, cardioprotective effects and dietary sources. J Nutr Biochem 1996;7(2):66-76.

8. Pereira DM, Valentao P, Pereira JA, Andrade PB. Phenolics: From chemistry to biology. Molecules 2009;14(6):1202-11.

9. Shrimali M, Jain DC, Darokar MP, Sharma RP. Antibacterial activity of Ailanthus excelsa (Roxb). Phytother Res 2001;15(2):165-6.

10. Joshi BC, Pandey A, Sharma RP, Khare A. Quassinoids from Ailanthus excelsa. Phytochemistry 2003;62(4):579-84.

11. Dhanasekaran S, Suresh B, Sethuraman M, Rajan S, Dubey R. Antifertility activity of Ailanthus excelsa Linn. in female albino rats. Indian J Exp Biol 1993;31(4):384-5.

12. Ogura M, Cordell GA, Kinghorn AD, Farnsworth NR. Potential anticancer agents vi. Constituents of Ailanthus excelsa (Simaroubaceae). 
Lloydia 1977;40(6):579-84.

13. Asolkar LV, Kakkar KK, Chakre OJ. Glossary of Indian Medicinal Plants with Active Principles. Part-I. New Delhi: Council of Scientific \& Industrial Research; 1992. p. 34-58.

14. Cordell GA, Ogura M, Farnsworth NR. Alkaloids constituents of Ailanthus excelsa. Lioydia 1978;41(2):166-8.

15. Said A, Rashed K, Tokuda H, Huefner A. Antitumor activity of Ailanthus excelsa Roxb. stem bark fractions and of canthin-6-one. IUFS J Biol 2012;71(1):112-21.

16. Nag A, Matai S. Ailanthus excelsa Roxb. (Simaroubaceae), a promising source of leaf protein. J Agric Food Chem 1994;35(5):1115-7.

17. Khan SA, Shamsuddin KM. Glaucarubol from Ailanthus excelsa. Phytochemistry 1980;19:2484-5.

18. Joshi BC, Pandey A, Chaurasia L, Pal M, Sharma RP, Khare A. Antifungal activity of the stem bark of Ailanthus excelsa. Fitoterapia 2003;74(7-8):689-91.

19. Said A, Tundis R, Hawas UW, El-Kousy SM, Rashed K, Menichini F, et al. In vitro antioxidant and antiproliferative activities of flavonoids from Ailanthus excelsa (Roxb.) (Simaroubaceae) leaves. Z Naturforsch C 2010;65(3-4):180-6.

20. McDonald S, Prenzler PD, Antolovich M, Robards K. Phenolic content and antioxidant activity of olive extracts. Food Chem 2001;73(1):73-84.

21. Chang C, Yang M, Wen H, Chern J. Estimation of total flavonoids content in propolis by two complementary colorimetric methods. J Food Drug Anal 2002;10(3):178-82.
22. Blois MS. Antimicrobial and antioxidant activity of Indian goose berry and galangal extracts. Nature 1958;29:1199-200.

23. Gülçin I. Antioxidant activity of L-adrenaline: A structure-activity insight. Chem Biol Interact 2009;179(2-3):71-80.

24. Rice-Evans CA, Miller NJ, Paganga G. Structure-antioxidant activity relationships of flavonoids and phenolic acids. Free Radic Biol Med 1996;20(7):933-56.

25. Rice-Evans C. Flavonoids and isoflavones: Absorption, metabolism, and bioactivity. Free Radic Biol Med 2004;36(7):827-8.

26. Jain N, Goyal S, Ramawat KG. Evaluation of antioxidant properties and total phenolic content of medicinal plants used in diet therapy during postpartum healthcare in Rajasthan. Int $\mathrm{J}$ Pharm Pharm Sci 2011;3(3):248-53

27. Mayachiew P, Devahastin S. Antimicrobial and antioxidant activity of Indian goose berry and galangal extracts. LWT Food Sci Techol 2008;41(7):1153-9.

28. Findik E, Ceylan M, Elmastas M. Isoeugenol-based novel potent antioxidants: Synthesis and reactivity. Eur J Med Chem 2011;46(9):4618-24

29. Khatri DK, Juvekar P, Juvekar AR. Phytochemical investigation and in vitro antioxidant activities Indigofera cordifolia seed extracts. Int $\mathrm{J}$ Pharm Pharm Sci 2013;5(2):71-5.

30. El-Sayad MM, El-Nahas HA, Hameed ES, El-Wakil EA. Investigation and antioxidant of phenolic compounds of the leaves of Gleditsia triacanthos L. Int J Pharm Pharm Sci 2013;5(2):172-7. 